\title{
Raw-appearing Restructured fish models made with Sodium alginate or Microbial transglutaminase and effect of chilled storage
}

\author{
Reestrutura do modelo peixe feito com transglutaminase alginato de sódio e microbiana e o efeito do \\ armazenamento refrigerado
}

\author{
Helena MORENO ${ }^{1 *}$, Jose CARBALLO ${ }^{1}$, Javier BORDERÍAS ${ }^{1}$
}

\begin{abstract}
Restructuring by adding Sodium Alginate or Microbial Transglutaminase (MTGase) using cold gelation technology make it possible to obtain many different raw products from minced and/or chopped fish muscle that are suitable for being used as the basis of new restructured products with different physicochemical properties and even different compositions. Special consideration must be given to their shelf-life and the changes that may take place during chilling, both in visual appearance and physicochemical properties. After chilled storage, the restructured models made with different muscular particle size and composition at low temperature $\left(5^{\circ} \mathrm{C}\right)$, it was observed that microbial growth limited the shelf-life to 7-14 days. Mechanical properties increased $(\mathrm{p}<0.05)$ during that time, and higher values were observed in samples elaborated by joining small muscle particle size than in those elaborated by homogenization. There was no clear increase in the cooking yield and purge loss, and no significant colour change $(\mathrm{p}>0.05)$ was detected during storage.

Keywords: cold binders; prototypes of restructured products; chilled storage.
\end{abstract}

\section{Resumo}

A reestruturação pela adição de Alginato de sódio ou Transglutaminase microbiana (MTGase) utilizando a tecnologia de gelificação pelo frio torna possível a obtenção de diversos produtos crus, a partir de músculo de peixe picado, que são apropriados para serem usados como base de novos produtos reestruturados com diferentes propriedades físico-químicas e até com composições diferentes. Consideração especial deve ser dada ao prazo de validade e às mudanças que podem ocorrer durante a refrigeração, tanto no aspecto visual como nas propriedades físico-químicas. Após o armazenamento refrigerado de modelos reestruturados feitos com diferentes tamanhos de partículas musculares e composições a baixas temperaturas $\left(5^{\circ} \mathrm{C}\right)$, foi observado um crescimento microbiano que limita o prazo de validade para 7 a 14 dias. As propriedades mecânicas aumentaram $(\mathrm{p}<0,05)$ durante o tempo, e os valores mais altos foram mais observados nas amostras elaboradas unindo partículas de músculo de tamanho pequeno do que nas elaboradas por homogeneização. O rendimento após cozimento e a perda de purga não apresentaram uma evolução clara nem foi detectada qualquer mudança significativa na cor.

Palavras-chave: ligantes frias; protótipos de produtos reestruturados; armazenamento refrigerado.

\section{Introduction}

Restructured fishery products can be processed from minced and/or chopped muscle in order to obtain new products from underutilized species or by-products after filleting commercial species with new and different appearance and texture. Various attempts have been made in the past few years to produce value-added fish products from low-commercialvalue cuts (RAMÍREZ, 2006; MORENO; CARBALLO; BORDERÍAS, 2010). These restructured fish products, seafood analogues in many cases, are mainly heated and therefore it looks like they are fully cooked. Nowadays, consumers are more interested in fresh products rather than in those that look like fully cooked. This has led to the need for making restructured products from chopped or minced raw fish muscle using technologies that do not included temperatures higher than $30-35^{\circ} \mathrm{C}$ (URESTI et al., 2006; MORENO; CARBALLO; BORDERÍAS, 2008; HERRANZ et al., 2012), temperature at which restructured products maintain the raw appearance.
Moreover, these fresh products are highly versatile in further processing because they can be consumed as fresh products in raw state or after being cooked. Two ingredients, sodium alginate and MTGase, have been considered in order to achieve cold-set protein gelation at temperatures low enough to prevent changes in the raw appearance or even in the flavour of the final products. Using these ingredients, it is possible to elaborate minimally processed products. Alginate is a hydrocolloid able to form thermo-stable gels without thermal treatment in the presence of calcium cations (MEANS; SCHMIDT, 1989; MORENO; CARBALLO; BORDERÍAS, 2008). It is believed that this gel interacts in some way with myofibrillar proteins. In fact, Shand, Sofos and Schmidt (1993) and Montero, Hurtado and Pérez-Mateos (2000) reported that these interactions are mainly electrostatic, occurring between the anionic groups on the alginate and the positively charged groups on the protein. On the other hand, Microbial Transglutaminase (protein- 
glutamine $\gamma$-glutamyltransferase) is an enzyme capable of catalyzing acyl-transfer reactions leading to cross-linking of proteins such as myosin, peptides, and primary amine by forming covalent bonds between the $\varepsilon$-amino group of lysyl residues and the $\gamma$-carboxamide group of glutaminyl residues of adjacent proteins (LEE et al., 1997; SUKLIM et al., 2004; PARK, 2005). The optimal activity of this enzyme is reached at $40-50{ }^{\circ} \mathrm{C}$ (URESTI et al., 2004; RAMÍREZ et al., 2006) although its activity has been reported from $0-70{ }^{\circ} \mathrm{C}$ (MOTOKI; SEGURO, 1998; AJINOMOTO..., 2009). Moreover, Kuraishi et al. (1997), Kuraishi, Yamazaki and Susa (2001) and Moreno, Carballo and Borderías (2008) reported that MTGase can be activated by adding sodium caseinate, which enhances formation of cross-linking at temperatures lower than $30{ }^{\circ} \mathrm{C}$ in meat and seafood products. Uresti et al. (2004) and Moreno, Carballo and Borderías (2009) confirmed these data in restructured products elaborated with different fish species and different muscle particle size.

It seems reasonable to suppose that if these ingredients enhance in any way protein bonding, this fact would induce some changes in the microorganism substrate that could modify in some way the pattern of spoilage during chilled storage. However, it has not been found studies of alginates and MTGase on stability in chilled storage.

The aim of this study was to investigate the behaviour of different hake restructured products with different muscle particle size and composition during chilled storage using coldset gelation by adding MTGase or sodium alginate.

\section{Materials and methods}

\subsection{Ingredients and samples preparation}

Frozen stored $\left(-20^{\circ} \mathrm{C}\right)$ hake fillets (Merluccius capensis) were used to make the two kinds of restructured fish muscle models: " $\mathrm{M}$ "- by homogenization using a cutting process and "P"- which was elaborated by joining muscle pieces of around $20 \mathrm{~mm}$. Restructured products were made adding either sodium alginate or MTGase as binders. Restructuring with sodium alginate (Lots MA and PA) consisted of: sodium alginate $(0.5 \%$ in MA and $0.2 \%$ in PA) (Degussa Texturant Systems España, S.A.; Barcelona, Spain), calcium chloride ( $0.1 \%$ in both) (Panreac Quimica, S.A.; Barcelona, Spain), sodium chloride (1.5\% in both) (Panreac Quimica, S.A.; Barcelona, Spain), and corn starch ( $0.8 \%$ in both) (Clearam CH-20, Dadelos, S.L., Valencia, Spain). In the case of restructuring with MTGase (Lots MM and $\mathrm{PM})$, the ingredients added were: sodium caseinate $(0.8 \%$ in both)(Julio Criado Goméz, S.A. Madrid, Spain) and microbial transglutaminase (1.0\% in MM and $0.5 \%$ in PM)(MTGase) dissolved in water (Activa WM [99\% maltodextrine and 1\% MTGase] Ajinomoto Co.; Tokyo, Japan); corn starch (0.8\% in both) (Clearam CH-20, Dadelos, S.L., Valencia, Spain); sodium chloride (4.0\% in MM and 1.5\% in PM) (Panreac Quimica, S.A.; Barcelona, Spain); and 5\% of water was also added.

Sample preparation was performed according to Moreno, Carballo and Borderías (2009) as follows: for MA and MM lots, the muscle pieces were finely homogenized with the ingredients in a refrigerated vacuum cutter (Stephan UM5, Stephan u. Söhne GmbH \& Co., Hameln, Germany). The order of addition and homogenization time for the samples prepared with sodium alginate was as follows: $\mathrm{NaCl}$ plus 1 minute homogenization, $\mathrm{CaCl}_{2}$ plus 1 minute homogenization, sodium alginate and 1 minute homogenization, and lastly, 1 more minute with corn starch. The final batter was homogenized again for one more minute (Table 1). In the case of MTGase sample (MM), the ingredients were incorporated as follows: $\mathrm{NaCl}$ plus 1 minute homogenization, sodium caseinate plus 1 minute homogenization, MTGase dissolved in water $5 \%$ of the total sample) and 1 minute homogenization, and lastly, 1 more minute with corn starch. The final dough was homogenized for one more minutes (Table 2). To prepare the PA and PM lots, the muscle pieces were ground using a meat mincer (FTS 11 Model, Van Dall SRL, Milan, Italy) through a plate with $20 \mathrm{~mm}$ holes and then mixed with the other components in a refrigerated kneading machine (Hobart N-504, Hobart Corporation, USA) preventing the muscle fibres from disintegrating, and thus the resulting sample retained muscle texture resulting in a more natural final texture batter. The order of ingredients addition was the same as described above, and the composition of the samples was as shown in Table 1 and Table 2. Starch (0.8\%) was added to all formulas as a constant because it is used regularly by the industry to avoid drip during storage. In all cases, round plastic plates (depth $16 \mathrm{~mm}$; diameter $96 \mathrm{~mm}$ ) were filled with the resulting batters and then placed in chilled storage $\left(5^{\circ} \mathrm{C}\right)$ for up to 21 days. Analyses were performed on days 1, 3, 7, 14, and 21 .

\subsection{Proximate analysis and apparent viscosity}

Moisture, fat, and ash contents of fish muscle were determined in quadruplicate (ASSOCIATION..., 2000). Crude protein contents were measured in quadruplicate using a LECO FP-2000 Nitrogen Determinator (Leco Corporation, St Joseph, MI, USA). Apparent viscosity was determined according to Borderías, Jiménez-Colmenero and Tejada (1985) in order to determine the functional quality of the raw material proteins. Thawed samples were homogenized with $5 \% \mathrm{NaCl}(1: 4), \mathrm{pH}=7$ (phosphate buffer). The homogenate was filtered through gauze and centrifuged for 10 minutes at $345 \mathrm{x}$ g to remove air bubbles.

Table 1. Restructured fish model made by adding sodium alginate.

\begin{tabular}{ccccc}
\hline Samples $^{*}$ & $\% \mathrm{NaCl}$ & \% Sodium alginate & $\% \mathrm{CaCl}_{2}$ & $\%$ Starch \\
\hline $\mathrm{MA}$ & 1,5 & 0,5 & 0,1 & 0,8 \\
$\mathrm{PA}$ & 1,5 & 0,2 & 0,1 & 0,8 \\
\hline
\end{tabular}

${ }^{*}$ MA: cutting process + alginate; PA: kneading small pieces + alginate.

Table 2. Restructured fish model made by adding microbial transglutaminase.

\begin{tabular}{cccccc}
\hline Sample & $\% \mathrm{NaCl}$ & \% MTGase & $\begin{array}{c}\text { \% Sodium } \\
\text { caseinate }\end{array}$ & \% Starch & \% $\mathrm{H}_{2} \mathrm{O}$ \\
\hline $\mathrm{MM}$ & 4,0 & 1,0 & 0,8 & 0,8 & 5,0 \\
$\mathrm{PM}$ & 1,5 & 0,5 & 0,8 & 0,8 & 5,0 \\
\hline
\end{tabular}


Measurements were made with a RV4 spindle using a Brookfield model DV-III rheometer (Stoughton, MA) and Rheocalc V 1.2 software. Measurements were carried out in triplicate, and results were expressed in centipoises $(\mathrm{cP})$.

\subsection{Microbiological analyses}

Samples were analysed in duplicate at different stages of chilled storage at $5{ }^{\circ} \mathrm{C}$ for 21 days. Analyses were performed on Plate Count Agar (PCA), (Merk, Germany) for total viable count following standard AFNOR AF V 08-051 (ASSOCIATION..., 1999). Counts were expressed as logarithms of colony forming units per gram $(\log \mathrm{cfu} / \mathrm{g})$.

\subsection{Protein solubility}

Protein solubility of final samples model was determined in triplicate, essentially according to the Ironside and Love (1985) procedure by analysing the amount of soluble protein in a chilled aqueous solution of $5 \% \mathrm{NaCl}$. Protein was analysed using a LECO FP analyzer, and the results were expressed as percentage of soluble protein over total protein.

\subsection{Scanning Electron Microscopy (SEM)}

All samples were examined by SEM after $24 \mathrm{~h}$ setting at chilled temperature. Samples were fixed with a mixture $(1: 1 \mathrm{v} / \mathrm{v})$ of formaldehyde (4\%) and glutaraldehyde $(0.2 \%)$ in $0.1 \mathrm{M}$ phosphate buffer ( $\mathrm{pH} 7.2$ ), post-fixed with $\mathrm{OsO}_{4}$ and ashes, dried in increasing concentrations of acetone, and critical-point dried as described by Moreno, Carballo and Borderías (2010) Samples were then sputter-coated (Balzer, SCD004) with gold/ palladium and examined in a Jeol Scanning Microscope (Jeol, JSC 6400, Akishima, Tokyo, Japan) at $20 \mathrm{kV}$.

\subsection{Purge loss}

To determine purge loss, samples were chilled stored for 21 days at $5{ }^{\circ} \mathrm{C}$. The differences in sample weight between different measurements on days: 1-3, 3-7, 7-14, and 14-21 were calculated to determine the drip during storage.

\subsection{Cooking yield}

Cooking yield was determined as reported by SánchezAlonso, Hají-Maleki and Borderías (2007) with slightly modifications. Samples were cooked in plastic bags at $90{ }^{\circ} \mathrm{C}$ during 10 minutes in an oven (Rational Combi-Master CM6). After the heat treatment, samples were left at room temperature for 1 hour, and the drip was collected and measured. Cooking yield was expressed as sample weight percentage after cooking. Cooking yield was determined in triplicate.

\subsection{Mechanical properties}

In view of the different physical properties determined by different particle sizes, Puncture Tests were carried out on samples MA and MM and Binding Tests on samples PA and PM. Both analyses were performed on room-tempered samples on days $1,3,7,14$, and 21 .
For the Puncture Test, one sample of each model MA and MM $16 \mathrm{~mm}$ thick and $96 \mathrm{~mm}$ in diameter was penetrated six times up to the breaking point at separate points. Tests were performed following Kim, Park and Yoon (2004) with some modification, as described by Moreno, Carballo and Borderías (2009). Breaking strength (BS) in N was determined on the force-deformation curves.

For the Binding Test, samples of models PA and PM (thickness $16 \mathrm{~mm}$; diam $96 \mathrm{~mm}$ ) were measured at room temperature on days $1,3,7,14$, and 21 to assess the ability of the muscle pieces to adhere to one another (strength), following a procedure similar to that described by Field et al. (1984) with small modifications, as described by Moreno, Carballo and Borderías (2010). The strength (S) was measured as the peak force $(\mathrm{N})$ required for a $1.9 \mathrm{~cm}$ ball to break through a fish slice mounted on a ring of $3.2 \mathrm{~cm}$ inner diameter. All mechanical properties were analysed using a TA-XT plus Texture Analyzer (Texture Technologies Corp., Scarsdale, NY, USA) at room temperature $\left(20-22^{\circ} \mathrm{C}\right)$.

\subsection{Colour measurement}

The colour of the samples was determined on a HunterLab Mini Scan MS/S-4000S (Hunter Associated Laboratory Inc., Reston, VA) using the CIE Lab scale $\left(\mathrm{D} 65 / 10^{\circ}\right)$, where $\mathrm{L}^{*}$ and $b^{\star}$ were the parameters measured on the restructured products, as described by Park (1995).

\subsection{Statistical analysis}

One way ANOVA was conducted using Statgraphics 2.1 (STSC Inc., Rockville, MD). The difference among means was analysed using the Tukey HSD test $(\mathrm{p}<0.05)$. Experiments were replicated twice.

\section{Results and discussion}

\subsection{Proximate analysis and apparent viscosity in raw material}

The main constituents of the raw material were moisture $80.92 \pm 0.99 \%$, total protein $16.59 \pm 0.8 \%$, fat $1.01 \pm 0.17 \%$, and ashes $1.45 \pm 0.03 \%$. Viscosity was $6898 \pm 337 \mathrm{cP}$. Protein aggregation, as shown in Table 3 , can be associated to the apparent viscosity of samples. On the scale used by Barroso,

Table 3. Salt-soluble protein in raw material and in the different samples.

\begin{tabular}{ccc}
\hline \multirow{2}{*}{ Samples $^{* *}$} & \multicolumn{2}{c}{ Storage period (days) } \\
\cline { 2 - 3 } & 0 & $1^{*}$ \\
\hline fish muscle & $60.33 \pm 0.59 \mathrm{a}$ & - \\
MA & - & $34.41 \pm 0.71 \mathrm{~b}$ \\
PA & - & $45.25 \pm 0.61 \mathrm{c}$ \\
MM & - & $24.05 \pm 0.67 \mathrm{~d}$ \\
PM & - & $41.41 \pm 1.04 \mathrm{c}$ \\
\hline Different letters mean statisticals differences during chilled storage $(\mathrm{p}<0.05){ }^{*} 5^{\circ} \mathrm{C} / 24 \mathrm{~h}$ \\
of setting. ${ }^{*}$ MA: cutting process + alginate; PA: kneading small pieces + alginate; \\
MM: cutting process + MTGase; PM: kneading small pieces + MTGase.
\end{tabular}


Careche and Borderías (1998), this fish muscle was rated between good and high.

\subsection{Microbial counts}

Microbial load started to increase slightly from day 7 of chilled storage (Table 4), mainly in lot PA followed by PM; however, on day 14, both samples were still within the Microbiological Standard limits for fish products $\left(10^{6} \mathrm{cfu} / \mathrm{g}\right)$ (BOLETÍN..., 1991).

MA and MM samples prepared by finely homogenization showed lower microbial counts than that of those made from small muscle pieces (PA and PM), regardless of the binder used (sodium alginate or MTGase). One reason for this could be that sodium chloride had been better spread through the dough in MA and MM samples because of the elaboration process. In PA and PM samples, due to the size of the muscle pieces forming the restructured models, distribution of $\mathrm{NaCl}$ was not as homogeneous as it was in MA and MM samples, and surely most of $\mathrm{NaCl}$ was spread over the surface of the muscle pieces and did not penetrate into the fish muscle pieces at all. On the other hand, differences on salt proportions between MM (4\%) and MA (1.5\%) lots did not produce any evident difference in microbial load evolution. Although sodium chloride has long been used as a preservative in meats due to its ability of inhibiting microbial growth by restricting the available water, in these samples, $\mathrm{NaCl}$ concentration seems to be not high enough to show this effect. Accordingly, Sallam and Samejima (2004) reported that addition of $\mathrm{NaCl}$ alone (3\%) did not have a significant effect on aerobic microorganisms. On the other hand, O'Connor et al. (1993) argued that $\mathrm{NaCl}$ should be added in combination with other additives, such us lactates, in order to successfully preserve refrigerated products.

\subsection{Protein solubility}

The relationship between soluble and insoluble protein in $5 \% \mathrm{NaCl}$ solution of restructured product samples is shown in Table 3. Protein solubility decreased $(\mathrm{p}<0.05)$ compared to the initial value in the fish muscle when samples were made with either alginate or MTGase. This decrease in solubility was greater in sample MM than in MA $(\mathrm{p}<0.05)$, indicating that MTGase links protein more effectively than sodium alginate. This evidence is consistent with the ultrastructure shown in Figure $1 b, c$, where the protein net is much more evident in samples made with MTGase than in those made with alginate. This is probably due to the greater degree of protein-protein interaction as consequence of MTGase that forms ( $\gamma$-glutamyl) lysine bonds between proteins, giving as a result a more homogeneous and compact structure.

Lower aggregation $(\mathrm{p}<0.05)$ was observed in samples PA and PM than in the samples MA and MM that were elaborated by fine homogenization This could be probably due to the fact that neither MTGase nor alginate can reach all the muscle protein effectively because of the elaboration process properties (Moreno, Carballo and Borderías, 2010). This means that only the proteins on the surface of muscle pieces are available to be linked, thus making for greater protein solubility.

\subsection{Ultrastructure}

Pictures were taken of the restructured models after 1 day of setting at $5{ }^{\circ} \mathrm{C}$ in order to examine the different net structures of samples made with both different binders and also the contribution of muscle pieces size. Comparing the pictures, it was observed that sample MM exhibited a more reticulated network matrix than that of sample MA (Figure la vs. 1b), which is consistent with the higher protein aggregation observed in the sample made with MTGase (Table 3). Figure 1c (PA) and 1D (PM) present quite similar structure, but in the sample with alginate a clearer network was discernible in some zones. This could suggest that alginate together with calcium chloride formed a parallel network to the muscle protein that could even interact with proteins. These results agree with those found by Montero, Hurtado and Pérez-Mateos (2000) and Pérez-Mateos, Solas and Montero (2002), who reported that the alginate network was connected in some way (normally electrostatic interactions) with muscular protein net.

\subsection{Purge loss}

Purge loss signals the presence of drip on the samples during chilled storage, generally as a consequence of myofibrillar proteins hydrolysis. This parameter is quite important to consumers because the exudates produce negative effects on the final product aspect and on texture properties (FAGAN; GORMLEY; MHUIRCHEARTAIGH, 2003).

Differences in weight between the samples on consecutive days of determination indicated no drip on the samples, which was also confirmed visually. This fact, suggests that the combination of sodium alginate or MTGase with corn starch $(0.8 \%)$ was good enough to bind the water during the chilled storage. The role of alginate as a water binder has been reported by various authors (PARK, 1995; LEE et al., 1997; ROSELL; ROJAS; DE BARBER, 2001). On the other hand, the

Table 4. Microbial counts during chilled storage (log cfu/g).

\begin{tabular}{cccccc}
\hline Samples* & 1 & 3 & 7 & 14 & 21 \\
\hline MA & $2.38 \pm 0.01 \mathrm{a}^{1}$ & $2.00 \pm 0.12 \mathrm{a}^{1}$ & $2.15 \pm 0.43 \mathrm{a}^{1}$ & $2.00 \pm 0.09 \mathrm{a}^{1}$ & $3.57 \pm 0.78 \mathrm{~b}^{1}$ \\
PA & $2.65 \pm 0.16 \mathrm{a}^{1}$ & $2.98 \pm 0.48 \mathrm{a}^{1}$ & $3.30 \pm 0.68 \mathrm{a}^{2}$ & $5.09 \pm 0.87 \mathrm{~b}^{2}$ & $5.77 \pm 0.99 \mathrm{~b}^{2}$ \\
MM & $2.15 \pm 0.32 \mathrm{a}^{1}$ & $2.15 \pm 0.39 \mathrm{a}^{1}$ & $2.00 \pm 0.17 \mathrm{a}^{1}$ & $2.00 \pm 0.36 \mathrm{a}^{1}$ & $3.96 \pm 0.58 \mathrm{~b}^{1}$ \\
PM & $2.98 \pm 0.25 \mathrm{a}^{1}$ & $2.81 \pm 0.57 \mathrm{a}^{1}$ & $2.99 \pm 0.23 \mathrm{a}^{2}$ & $3.23 \pm 0.53 \mathrm{a}^{3}$ & $6.66 \pm 0.89 \mathrm{~b}^{2}$ \\
\hline
\end{tabular}

${ }^{*}$ Different letters mean statistical differences during chilled storage $(\mathrm{p}<0.05)$. Different numbers mean statistical differences between samples $(\mathrm{p}<0.05){ }^{* *} \mathrm{MA}$ : cutting process + alginate; PA: kneading small pieces + alginate; MM: cutting process + MTGase; PM: kneading small pieces + MTGase. 


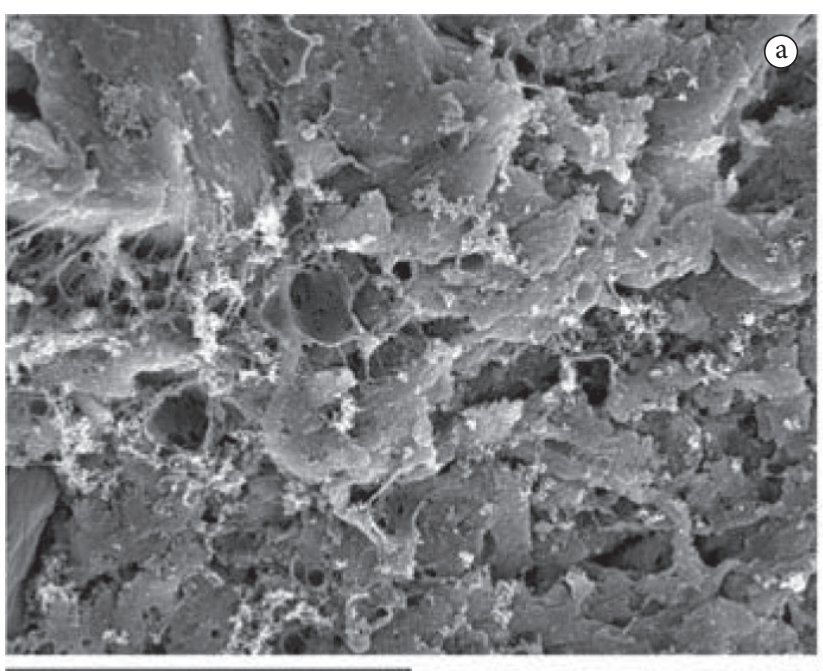

$60 \mu \mathrm{m}$

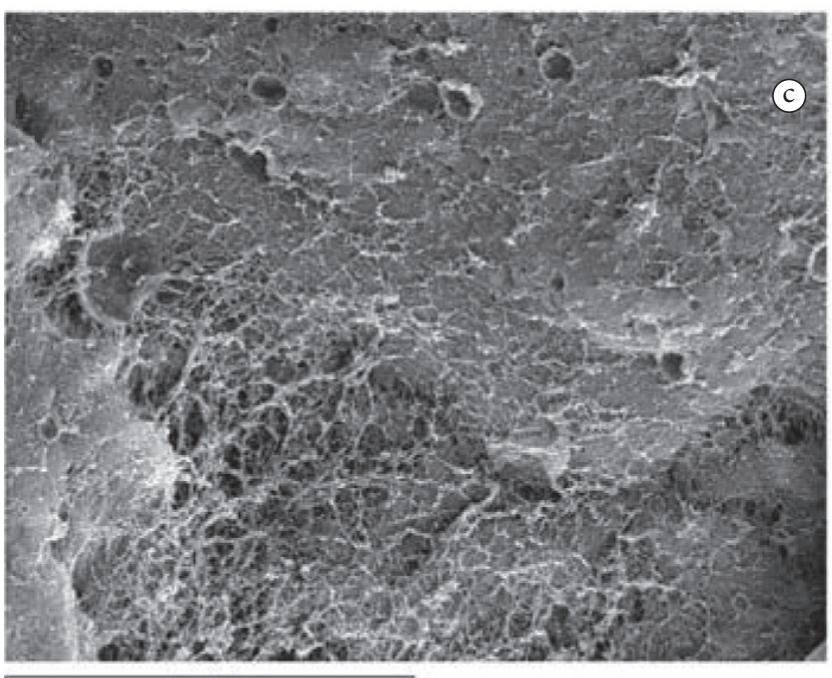

$60 \mu \mathrm{m}$

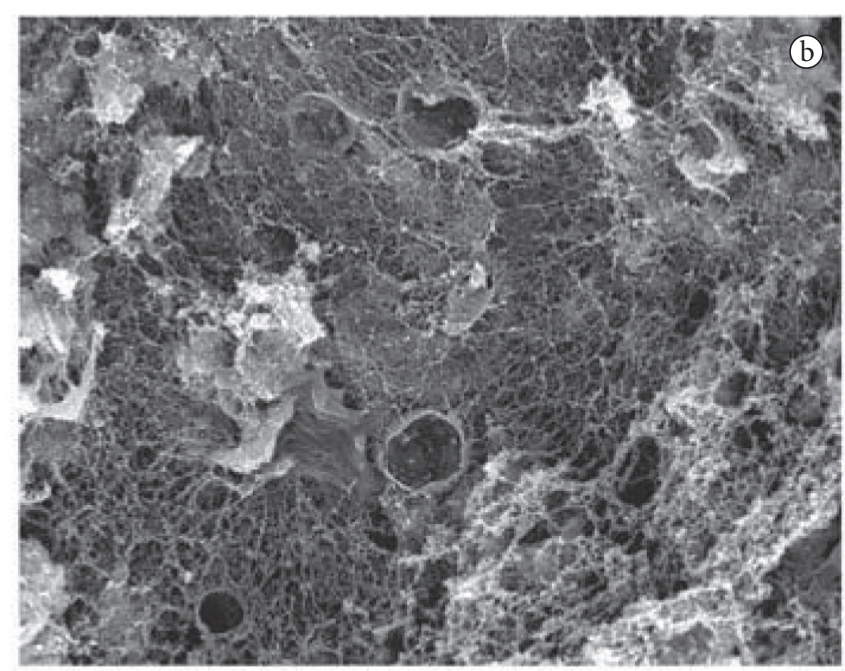

$60 \mu \mathrm{m}$

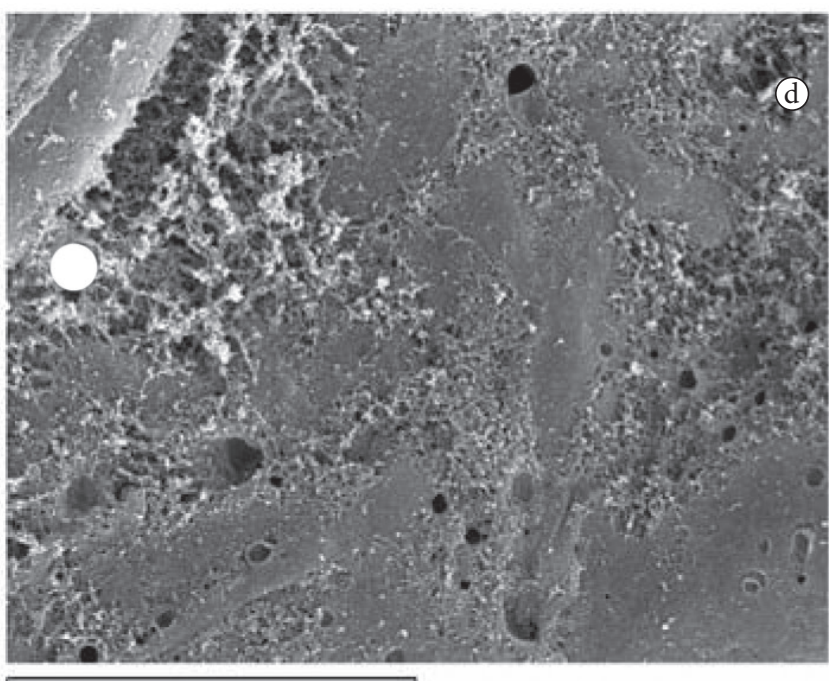

$60 \mu \mathrm{m}$

Figure 1. Scanning electron microscopy micrographs ( $\times 1000$ magnification) of restructured fish models after 1 day of setting at $5^{\circ} \mathrm{C}$. a) $\mathrm{MA}(\mathrm{cutting}$ process + alginate), b) MM (cutting process + MTGase), c) PA (kneading small pieces + alginate), d) PM (kneading small pieces + MTGase).

role of MTGase in water retention has been stated to be more controversial, and different authors have obtained different results concerning its ability of bonding water (KURAISHI et al., 1997; BUSHUK, 1998; FISHER, 1999). Furthermore, the role of starch linking water has to be considered.

\subsection{Cooking yield}

Cooking yield was clearly dependent on the type of formulation (Figure 2). Restructured products made with MTGase (PM and MM) exhibited lower cooking yield than that of the samples made with added alginates (PA and MA). This suggests that, if no differences between alginate and MTGase combined with starch were observed in terms of purge loss (raw state), it is then evident that as consequence of cooking process $\left(90^{\circ} \mathrm{C}\right)$, alginate bind water more effectively than MTGase. In fact, several authors have reported that the addition of MTGase

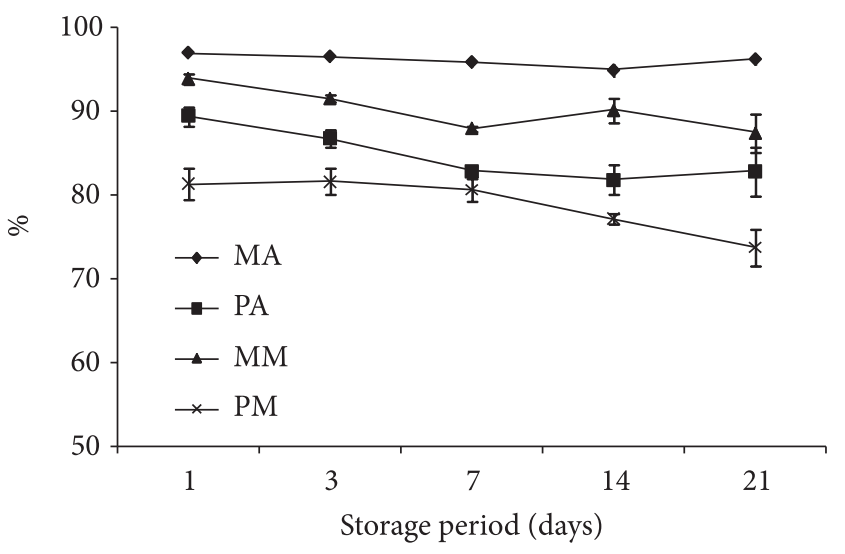

Figure 2. Cooking yield increase $\left(90^{\circ} \mathrm{C} / 10 \mathrm{~min}\right)$ in percentage during chilled storage. MA: cutting process + alginate, PA: kneading small pieces + alginate, MM: cutting process + MTGase and PM: kneading small pieces + MTGase. 
did not influence water binding ability expected (KERRY et al., 1999; O’KENNEDY; KELLY, 2000).

With regard to the different elaboration process (lots " $\mathrm{M}$ " and Lots "P"), water retention after cooking was higher in MA and MM samples than in PA and PM samples. This fact is probably a consequence of the greater interaction among proteins-water-ingredients. In addition, in proteins of cold water species, such as hake, pre-gelation occurs at low temperatures after salt-induced solubilisation due to the endogenous transglutaminase activity present in the muscle (LANIER; CARVAJAL; YONGSAWATDIGUL, 2005). After the setting process, the water is bound in a protein-protein net that constitutes the gel. When restructured products are elaborated by using small muscle pieces, the ingredients do not blend well with the pieces and therefore neither with myofibrillar proteins. Therefore, the formed net is not as well consolidated as it is in the $\mathrm{M}$ samples, as can also be observed in the microphotographs of the PA and PM samples (Figure 1c, d) with a protein net only partially formed.

\subsection{Mechanical properties}

As shown in Figure 3a, breaking strength (BS) increased sharply over the first 14 days of chilled storage $(p<0.05)$. This increase was observed in both samples, raw and cooked, but to a more extent degree in the cooked samples due to covalent bonds formed between proteins because of the cooking process. After heat treatment of the samples made by finely homogenization adding both alginate and MTGase (MAc and MMc), BS was considerably greater than that in the corresponding raw samples (MAr and MMr). In both cases, in addition to the different bonds formed as a result of sodium alginate (electrostatic interactions between myofibrillar proteins and alginate) or MTGase ( $\gamma$-glutamyl)lisine bonds between proteins) addition, there were disulfide bonds that were formed as consequence of the heat treatment (MASAKI, 2001; GERRARD et al., 2002). With regard to the evolution observed in the raw state samples, Moreno, Carballo and Borderías (2010) reported that at $5{ }^{\circ} \mathrm{C}$ some residual MTGase activity was observed up to 12-24 hours after the addition. Moreover, breaking strength increased because other covalent bonds between proteins were formed besides those formed by MTGase. Similar effects were found by Cofrades et al. (2006) in a study on MTGase effects in restructured beef products. The authors reported that MTGase and storage time had a linear effect on samples hardness. On the other hand, and regardless of the treatment, breaking strength was greater in samples made with sodium alginate than in samples made with MTGase, probably because there are more free proteins to be bound in the course of chilled storage by the reinforcement of hydrogen bonds during refrigeration (KIM; PARK; YOON, 2004). They seem to confer higher texture to samples than the bonds because of MTGase.

Binding Tests were carried out on samples made with pieces (PA and $\mathrm{PM}$ ) to determine the stress rupture strength due to a binding force. As shown in Figure 3b, the strength (N) of samples increased after the heat treatment, as expected, due to the enhancement of disulfide bonding induced by the heat treatment (MASAKI, 2001; GERRARD et al., 2002). An increase in strength during chilled storage, up to day $7(\mathrm{p}<0.05)$ in heated samples were observed, while strength remained constant in raw samples $(p<0.05)$. As previously noted, these changes in strength in cooked samples, particularly in samples added with MTGase, was due not only to the formation of disulfide bonds as a consequence of heat treatment but also to the bonds formed because of MTGase activity.

\subsection{Colour measurement}

Results of colour measurement during storage in both raw and cooked samples are shown in Table 5. Lightness slightly increased during chilled storage. Moreover, samples made with small muscle pieces (PA and PM) showed lower values than MA and MM samples, regardless of whether MTGase or sodium alginate was added. This is more likely due to the type of mixing and binding than to the effects of alginate or MTGase. In the case of $b^{*}$ values, the trend was fairly similar to that observed
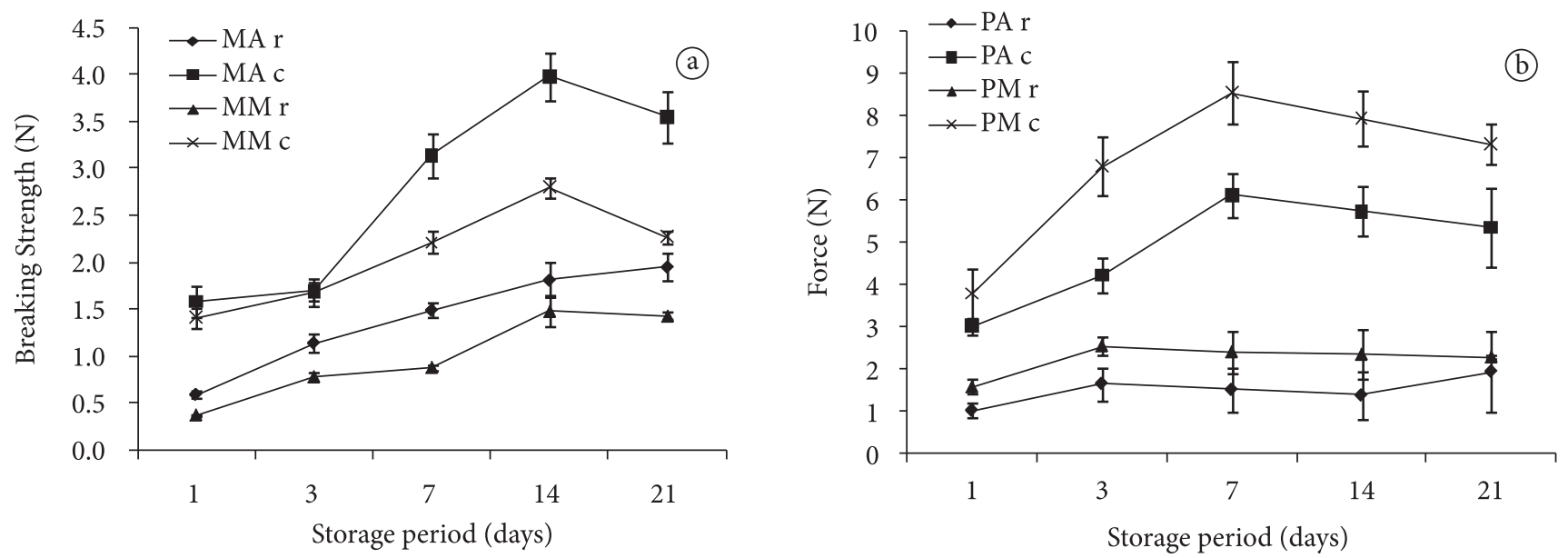

Figure 3. a) Evolution of Breaking strength $(\mathrm{N})$ during chilled storage of MA (cutting process + alginate) and MM: (cutting process + MTGase) samples. b) Evolution of Force $(\mathrm{N})$ during chilled storage of samples PA (kneading small pieces + alginate) and PM (kneading small pieces + MTGase). r: raw state, c: cooked. 
Table 5. Evolution of colour measurement during chilled storage.

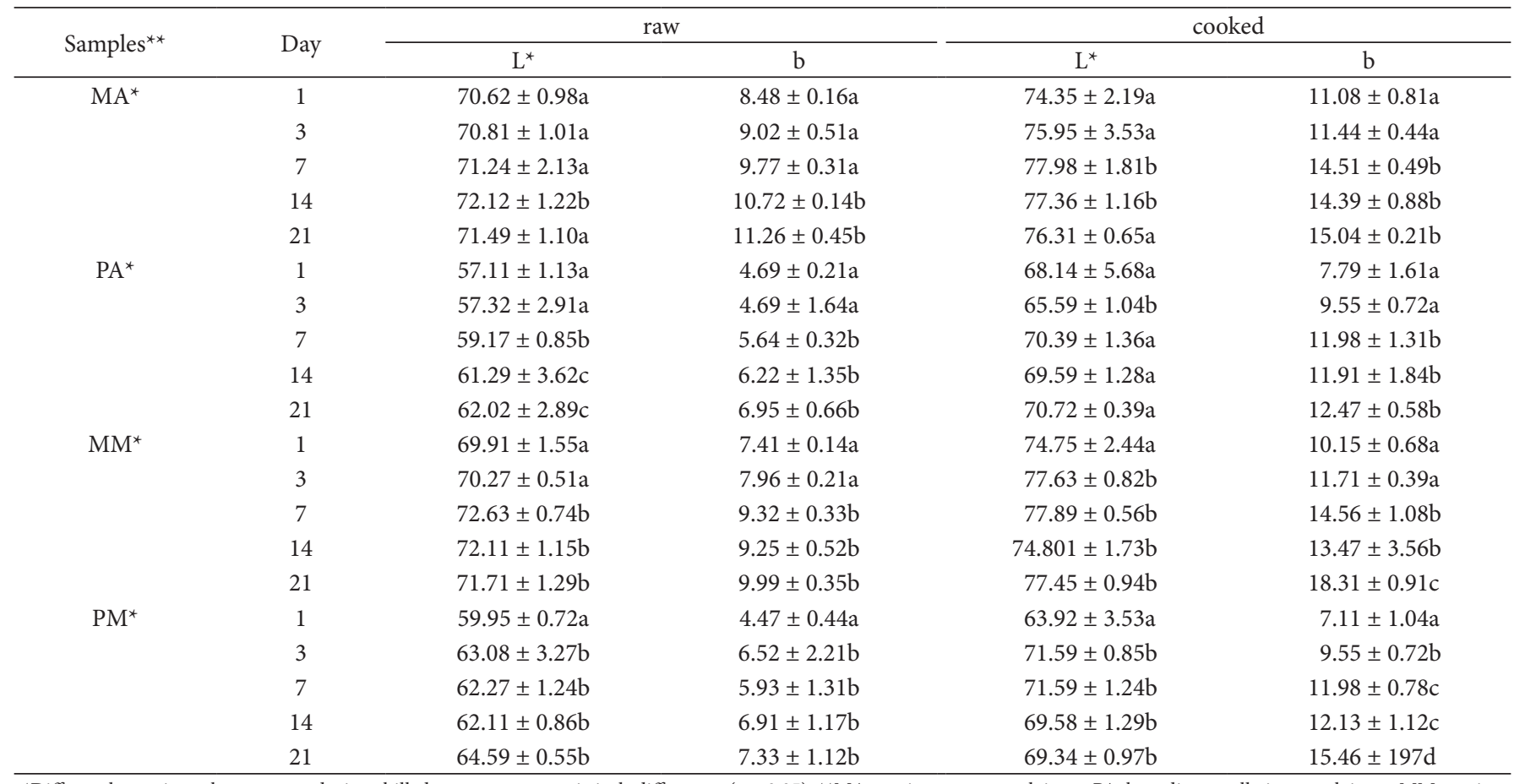

${ }^{\star}$ Different letters in each parameter during chilled storage mean statisticals differences $(\mathrm{p}<0.05)$. ${ }^{\star *} \mathrm{MA}$ : cutting process + alginate; PA: kneading small pieces + alginate; MM: cutting process + MTGase; PM: kneading small pieces + MTGase.

for $L^{*}$. Fagan, Gormley and Mhuircheartaigh (2003) reported similar results in a study on different fish muscle species during different storage periods.

It was observed that after cooking, $\mathrm{L}^{*}$ generally increased slightly during storage. If these values are compared to those of the unheated samples, raw samples presented higher values for both $L^{*}$ and $b^{*}$. The variation in $b^{*}$ was greater than that in the raw samples, and also $b^{\star}$ increased during storage. This is mainly due to protein denaturation as a consequence of the heat treatment (TORNBERG, 2007).

\section{Conclusions}

The present study shows that in the experimental conditions considered, the samples successfully withstood at least 14 days in chilled storage at $5{ }^{\circ} \mathrm{C}$. Right after their elaboration with either MTGase or alginate, the samples made by cutter have similar strength independently of their structure. During chilled storage, the strength increases in a higher extent in samples with alginate. Moreover, MTGase conferred higher mechanical properties to the samples elaborated by joining small muscle pieces than did the sodium alginate, even after samples were cooked. Cooking yield was slightly higher in the samples elaborated using sodium alginate regardless of the process.

\section{Acknowledgments}

The authors acknowledge the fellowship provided by the Consejo Superior de Investigaciones Científicas (CSIC) (program \#I3P-2004), the technicians at Institute of Food
Science Technology and Nutrition (ICTAN) for the excellent pilot plant and laboratory assistance, and Maite Solas for the excellent samples micrographs.

\section{References}

AJinomoto MANUAL. Activa Wm Ajinomoto Co’s Transglutaminase Activa. Modification of Physical properties of Protein. 2009. Disponívem em: <http://meat-n-more.info/test/ englisch/activa/back/back01.htm $>$.

ASSOCIATION FRANÇAISE DE NORMALISATION - AFNOR. Norm AF V 08-051: Collection of Microbiological Standards for foods and assimilated articles and other health-related physicochemical parameters. AFNOR, 1999.

ASSOCIATION OF OFFICIAL ANALYTICAL CHEMISTRY - AOAC. Official methods of analysis Association of Official Analytical Chemistry. 17th ed. Maryland: AOAC, 2000.

BARROSO, M.; CARECHE, M.; BORDERÍAS, A. J. Quality control of frozen fish using rheological techniques. Trends in Food Science and Technology, n. 9, v. 6, p. 223-229, 1998. http://dx.doi. org/10.1016/S0924-2244(98)00047-8

BOLETÍN OFICIAL DEL ESTADO - BOE. By approving the microbiological standards, limits on heavy metals content and analytical methods for determination of heavy metals for fishery products and aquaculture (195, 15/08/91). BOE, 1991.

BORDERÍAS, A.; JIMÉNEZ-COLMENERO, F.; TEJADA, M. Parameters affecting viscosity as a quality-control for frozen fish. Marine Fishery Review, v. 47, n. 4, p. 43-45, 1985.

BUSHUK, W. Interactions in wheat doughs. In: HAMMER, R. J.; HOSNEY, R. C. Interactions: The key to cereal quality. St. Paul: American Assoc Cereal Chem, Inc.,1998. p. 1-16. 
COFRADES, S. et al. Walnut, microbial transglutaminase and chilling storage time effects on salt-free beef batter characteristics. European Food Research International, v. 222, n. 3-4, p. 458-466, 2006. http:// dx.doi.org/10.1007/s00217-005-0017-y

FAGAN, J. D.; GORMLEY, T. R.; MHUIRCHEARTAIGH, M. U. Effect of freeze-chilling in comparison with fresh, chilling and freezing, on some quality parameters of raw whiting, mackerel and salmon portions. LWT-Food Science and Technology, v. 23, p. 647-655, 2003. http://dx.doi.org/10.1016/S0023-6438(03)00084-7

FIELD, R. A. et al. An objective measurement for evaluation of bind in restructured lamb roasts. Journal of Texture Studies, v. 15, n. 2, p.173-178, 1984. http://dx.doi.org/10.1111/j.1745-4603.1984. tb00377.x

FISHER, R. A. Seafood restructuring using cold-set binding technology. Gloucester Point: Virginia Sea Grant Marine Advisory Program, Virginia Institute of Marine Science, College of William and Mary, 1999. VSGPCP-G-99-002:16.

GERRARD, J. A. et al. Effects of microbial transglutaminase on the wheat proteins of bread and croissant bough. Journal of Food Science, v. 66, n. 6, p.782-786, 2002. http://dx.doi. org/10.1111/j.1365-2621.2001.tb15172.x

HERRANZ, B. et al. Effect of alkalis on konjac glucomannam gels for use as potencial gelling agents in restructure seafood products. Food Hydrocolloids, v. 27, n. 1, p. 145-153, 2012.

IRONSIDE, J. I. M.; LOVE, R. M. Studies on protein denaturation in frozen fish. Biological factors influencing the amounts of soluble and insoluble proteins present in the muscle of the North Sea Cod. Journal of the Science of Food and Agriculture, v. 9, p. 597617, 1985. http://dx.doi.org/10.1002/jsfa.2740090911

KERRY, J. F.; MORRISSEY, P. A.; BUCKLEY, D. J. The rheological properties of exudates from cured porcine muscle: effects of added carrageenans and whey protein concentrate/carrageenan blends. Journal of the Science of Food and Agriculture, v. 79, n. 1, p. 71-78. http://dx.doi.org/10.1002/(SICI)1097-0010(199901)79:1<71::AIDJSFA184>3.0.CO;2-0

KIM, B. Y.; PARK, J.; YOON, W. Rheology and texture properties of surimi gels. In: PARK, J. W. (Ed.). Surimi and surimi seafood. Boca Raton: CRC Press, 2004.

KURAISHI, C. et al. Production of restructured meat using microbial transglutaminase without salt or cooking. Journal of Food Science, v. 62, n. 3, p. 488-490, 1997. http://dx.doi. org/10.1111/j.1365-2621.1997.tb04412.x

KURAISHI, C.; YAMAZAKI, K.; SUSA, Y. Transglutaminase: Its utilization in the food industry. Food Review International, v. 17, n. 2, p. 221-246, 2001. http://dx.doi.org/10.1081/FRI-100001258

LANIER, T. C.; CARVAJAL, P.; YONGSAWATDIGUL, J. Surimi gelation Chemistry. In: PARK, J. W. (Ed.). Surimi and surimi seafood. 2nd ed. Taylor \& Francis group, 2005. p. 435-477.

LEE, H. G. et al. Transglutaminase effects on low temperature gelation of fish protein sols. Journal of Food Science, v. 62, n. 1, p. 20-24, 1997. http://dx.doi.org/10.1111/j.1365-2621.1997.tb04359.x

MASAKI, L. Thermal stability and enzymatic activity of a smaller lysozyme from silk moth (Bombyx mori). Journal of Protein Chemistry, v. 20, p. 107-117, 2001. PMid:11563690. http://dx.doi. org/10.1023/A:1011073206353

MEANS, W. J.; SCHMIDT, G. R. Algin calcium gel as a raw and cooked binder in structured beef steaks. Journal of Food Science, v. 51, n. 1, p. 60-65, 1986. http://dx.doi.org/10.1111/j.1365-2621.1986. tb10836.x
MONTERO, P.; HURTADO, J. L.; PÉREZ-MATEOS, M. Microstructural behaviour and gelling characteristics of myosystem protein gels interacting with hydrocolloids. Food Hydrocolloids, v. 14, n. 5, p. 455-461, 2000. http://dx.doi.org/10.1016/S0268-005X(00)00025-4

MORENO, H. M.; CARBALLO, J.; BORDERÍAS, A. J. Influence of Alginate and Microbial Transglutaminase as binding ingredients on restructured fish muscle processed at low temperature. Journal of the Science of Food and Agriculture, v. 88, p. 1529-1536, 2008. http://dx.doi.org/10.1002/jsfa.3245

MORENO, H. M.; CARBALLO, J.; BORDERÍAS, A. J. Study of two different cold restructuring processes using two different qualities of hake (Merluccius capensis) muscle, with addition of microbial transglutaminase. Journal of the Science of Food and Agriculture, v. 89 , n. 8, p. 1346-1351, 2009. http://dx.doi.org/10.1002/jsfa.3592

MORENO, H. M.; CARBALLO, J.; BORDERÍAS, A. J. Gelation of fish muscle using microbial transglutaminase and the effect of sodium chloride and pH levels. Journal of Muscle Food, v. 21, p. 433450, 2010. http://dx.doi.org/10.1111/j.1745-4573.2009.00193.x

MOTOKI, M.; SEGURO, K. Transglutaminase and its use for food processing. Trends in Food Science and Technology, v. 9, n. 5, p. 204-210, 1998. http://dx.doi.org/10.1016/S0924-2244(98)00038-7

O'CONNOR, P. L. et al. Sodium lactate/sodium chloride effects on sensory characteristics and shelf-life of fresh ground pork. Journal of Food Science, v. 58, p. 978-980, 986, 1993.

O'KENNEDY, B. T.; KELLY, P. M. Evaluation of milk protein interactions during acid gelation using a simulated yoghurt model. Milchwissenschaft, v. 55, n. 4, p. 187-190, 2000.

PARK, J. W. Surimi gel colours as affected by moisture-content and physical conditions. Journal of Food Science, v. 60, n. 1, p. 1518, 1995. http://dx.doi.org/10.1111/j.1365-2621.1995.tb05596.x

PARK, J. W. Ingredient technology for surimi and surimi seafood. In: PARK, J. W. (Ed.). Surimi and surimi seafood. 2nd ed. Boca Raton: CRC Press, 2005. p. 649-707. http://dx.doi. org/10.1201/9781420028041.ch13

PÉREZ-MATEOS, M.; SOLAS, T.; MONTERO, P. Carrageenans and alginate effect on properties of combines pressure and temperature in fish mince gels. Food Hydrocolloids, v. 16, p. 225-233, 2002. http://dx.doi.org/10.1016/S0268-005X(01)00086-8

RAMíREZ, J. A. et al. Application of Microbial Transglutaminase to improve mechanical properties of surimi from silver carp. Science and Technology Alimentarie, v. 3, n.1, p. 21-28, 2006.

RAMÍREZ, J. A. et al. Production of low-salt restructured products from Mexican flounder (Clyclopsetta chittendeni) using microbial transglutaminase or whey protein concentrate as binders. European Food research Technology, v. 223, p. 341-345, 2006. http://dx.doi. org/10.1007/s00217-005-0210-z

ROSELL, C. M.; ROJAS, J. A.; DE BARBER, C. B. Influence of hydrocolloids on dough rheology and bread quality. Food Hydrocolloids, v. 15, n.1, p. 75-81, 2001. http://dx.doi.org/10.1016/ S0268-005X(00)00054-0

SALLAM, K. H. I.; SAMEJIMA, K. Microbial and chemical quality of ground beef treated with sodium lactate and sodium chloride during refrigerated storage. LWT-Food Science and Technology, v. 37, p. 865-871, 2004. PMid:17330155 PMCid:1805706. http:// dx.doi.org/10.1016/j.lwt.2004.04.003

SÁNCHEZ-ALONSO, I.; HAJÍ-MALEKI, R.; BORDERÍAS, A. J. Wheat fibber as a functional ingredient in restructured fish product. Food Chemistry, v. 100, p. 1037-1043, 2007. http://dx.doi.org/10.1016/j. foodchem.2005.09.090 
SHAND, P. J.; SOFOS, J. N.; SCHMIDT, G. R. Properties of algin calcium and salt phosphate structured beef rolls with added gums. Journal of Food Science, v. 58, n. 6, p. 1224-1230, 1993. http:// dx.doi.org/10.1111/j.1365-2621.1993.tb06153.x

SUKLIM, K. et al. Effect of cold-set binders: Alginates and microbial transglutaminase on the physical properties of restructured scallops. Journal of Texture Studies, v. 35, n. 6, p. 634-642, 2004. http:// dx.doi.org/10.1111/j.1745-4603.2004.35514.x

TORNBERG, E. Effects of heat on meat proteins-Implications on structure and quality of meat products. Review in Meat Science, v. 70, p. 493-508, 2007. PMid:22063748. http://dx.doi.org/10.1016/j. meatsci.2004.11.021

URESTI, R. M. et al. Use of dairy proteins and microbial transglutaminase to obtain low-salt fish products from filleting waste from silver carp (Hypophthalmichthys molitrix). Food Chemistry, v. 86, n. 2, p. 257-262, 2004. http://dx.doi.org/10.1016/j.foodchem.2003.09.033

URESTI, R. M. et al. Effects of combining microbial transglutaminase and high pressure processing treatments on mechanical properties of heat-induced gels prepared from arrowtooth flounder (Atheresthes stomias). Food Chemistry, v. 94, p. 202-209, 2006. http://dx.doi. org/10.1016/j.foodchem.2004.11.005 